\title{
AGROECOLOGIA E CIÊNCIA, UM PARALELO HISTÓRICO
}

Walter Colli ${ }^{1}$

O texto de Navarro (2013), publicado no número anterior desta revista, é uma análise aguda a respeito de uma terminologia que vem sendo usada por alguns na área da Agronomia e que carece de fundamentos sólidos: a agroecologia. O autor mostra, de forma lógica, que, embora o termo seja usado, inclusive em textos governamentais e em editais do CNPq, culminando com o Decreto $n^{0} 7.794$, de 20 de agosto de 2012, é difícil definí-lo se tomado sob o ângulo estritamente científico.

Assim, em alguns textos produzidos por esse setor leem-se afirmações, no mínimo duvidosas:

\begin{abstract}
A academia geralmente conhece as condições em laboratório, de livros e estudos, e as pessoas que vivem disso conhecem a prática. Mas esse diálogo é muito difícil porque, por exemplo, dentro da academia tem um mito de que a ciência só pode ser feita em condições controladas. Tudo o que é considerado tradicional é chamado de superstição, conhecimento intuitivo, etc. ${ }^{2}$ (CONSEA, 2012).
\end{abstract}

Nessa entrevista, que retrata bem o pensamento dessa corrente, segundo os textos que a suportam, geralmente boletins do Conselho Nacional de Segurança Alimentar e Nutricional (CONSEA), sugere-se que o conhecimento transmitido e criado nas escolas de Agronomia é "teórico" e que o conhecimento real é o conhecimento "prático" dos agricultores, sempre referidos como "camponeses e camponesas" ou, quando é necessário ser mais abrangente, "povos do campo, das águas e das florestas" (ENU, 2012).

A professora Siliprandi, em entrevista concedida ao Boletim do CONSEA, critica um dos fundamentos do método da Ciência experimental que é o controle. Chamar a agroecologia de ciência, e ao mesmo tempo dizer que o controle das condições experimentais é um mito, aniquila qualquer veleidade de inscrever a agroecologia no rol das disciplinas científicas. Qualquer observação sem condições controladas dificilmente po-

\footnotetext{
${ }^{1}$ Médico, Doutor em Bioquímica. Professor. Livre-docente da Universidade de São Paulo (USP). Membro da Academia Brasileira de Ciências e da Academia de Ciências do Mundo em Desenvolvimento (TWAS). walcolli@usp.br

2 Entrevista dada por Emma Siliprandi, representante da Associação Brasileira de Agroecologia (ABA) e do Brasil - na Sociedade Científica Lationoamericana de Agroecologia (Socla).
} 
derá ser repetida. Sem repetição, não se obtêm dados confiáveis e passíveis de análise estatística.

Na verdade, é indiferente se há quem acredite que está fundando uma nova ciência, desde que não a confronte com o edifício solidamente erigido pela Ciência por meio de muitos experimentos, repetições, abordagens distintas e contínuas verificações práticas e teóricas. Pior é o proselitismo em sala de aula, distorcendo mentes jovens e despreparadas.

Na mesma entrevista relatada, de Emma Siliprandi, há a seguinte afirmação: “Então, a nossa grande prioridade na academia hoje é convencer os próprios colegas, fazer o embate político dentro da universidade, e dizer que sem prática a teoria não vale nada. E que você precisa dialogar" (CONSEA, 2012).

Ora, ciência não se faz com "embate político" e muito menos o arcabouço da Biologia que sustenta as disciplinas agronômicas é "teórico", na acepção derrogatória, como inútil, emprestada à palavra, quando confrontada com a "sabedoria prática" dos "camponeses" e das "camponesas". Esse tipo de discurso estabelece uma contraposição falsa entre uma atividade baseada em hipóteses e experimentação racional e outra baseada em uma prática tradicional, mas sem fundamentos científicos. É óbvio que os cientistas estão sempre atentos a práticas agrícolas vantajosas, delas extraindo as explicações e as formas de aperfeiçoamento dessas observações. É o caso, por exemplo, do uso de Bacillus thuringiensis para controlar os ataques de lagartas nas plantações. Os agricultores orgânicos usam aspergir esporos desse bacilo sobre suas plantações. A Ciência perguntou qual o mecanismo pelo qual o bacilo mata a lagarta e acabou por descobrir uma família de genes que produzem as proteínas Cry, que perfuram o intestino da lagarta, matando-a. Por meio de técnicas de engenharia genética, os genes das proteínas Cry foram introduzidos em milho, por exemplo, fazendo com que a própria planta, ao expressar a proteína, defenda-se da lagarta.

É extremamente perigoso quando se adjetiva a Ciência: ciência acadêmica, ciência teórica, ciência prática, ciência burguesa, ciência capitalista, ciência popular. Quando se vive em uma democracia, esses conceitos são tratados como esquisitices sem maiores consequências, mas quando o autoritarismo se instala, os grupos que professam essas quase religiões podem ser fonte de inspiração para a perseguição política à Ciência e aos cientistas.

Após uma análise percuciente, Navarro (2013) conclui que apelidar a agroecologia de Ciência ou disciplina científica é apenas "um estratagema político de confrontar o dominante padrão técnico da agricultura moderna".

\section{A INTROMISSÃO DA POLÍTICA NA CIÊNCIA}

Sir Henry Dale, que foi Presidente da Royal Society, assim se manifestou: "desde as ameaças históricas que forçaram Galileu a retratar-se houve muitas tentativas de suprimir ou distorcer a verdade científica em favor de credos estranhos à Ciência, mas nenhuma dessas tentativas foi bem sucedida por muito tempo" (PRINGLE, 2008).

De fato, a Ciência é infensa a afirmações que aparecem como verdades reveladas. Ideias preconcebidas, ideologias, afirmações insuscetiveis de comprovação não fazem par- 
te do método de conhecer a verdade. Por isso, o artigo de Navarro (2013) estimulou-nos a contar uma história que poucos conhecem e que ocorreu no século passado. A verdade científica foi substituída pela vontade oficial por decreto.

\section{A GENÉTICA E A AGRICULTURA NA UNIÃO SOVIÉTICA}

Nikolai Ivanovich Vavilov foi um dos maiores biólogos russos na primeira metade do século XX. Tendo nascido em 1887 (Moscou) e se graduado no Instituto de Agricultura Petrovskaya, a "Petrovka" em 1911, colheu em cheio as ideias que proliferavam na Biologia, em consequência da publicação das Leis de Mendel, em 1865, e de sua redescoberta no início do século XX. No período de 1912 a 1914, foi estudar na França, na Alemanha e na Inglaterra, particularmente com o famoso William Bateson, no Instituto de Horticultura John Innes em Merton, próximo a Londres (PRINGLE, 2008).

Vavilov não era um cientista teórico. Seu desejo era melhorar as variedades de grãos na Rússia, usando cruzamentos entre plantas a fim de obter variedades resistentes a difíceis condições climáticas, por exemplo. Confiava integralmente na nova Ciência, a Genética, para obter variedades cada vez mais bem adaptadas às diferentes condições climáticas no extenso território russo. Motivava-o a vontade de contribuir com a produção de grãos em quantidade suficiente para o povo russo, que passou fome nos primeiros 50 anos do século passado (PRINGLE, 2008).

Ele acreditava que, indo aos centros de origem, como chamava os locais onde a prática agrícola era milenar, iria encontrar sementes com características genéticas que poderiam ser introduzidas por cruzamento nas diferentes variedades.

Assim, em 1916, foi ao norte da Pérsia (Irã) com o Exército Imperial. Em 1924, promoveu extensa expedição ao Afeganistão. Já no biênio 1926 - 1927, organizou expedição à Abissínia (Etiópia) e visitou o norte da África, o Oriente Médio e os países mediterrâneos, publicando o livro "Estudos sobre a origem das plantas cultivadas". No biênio 1932 - 1933, fez uma longa expedição ao continente americano, incluindo EUA, Canadá, México, América Central, Colômbia, Peru, Bolívia, Chile, Argentina, Uruguai, Brasil, Trinidad, Porto Rico e Cuba (PRINGLE, 2008).

Em todas essas viagens, Ele coletava uma grande quantidade de sementes que despachava para Leningrado, constituindo, assim, uma coleção, ainda existente, de sementes do mundo todo. Na verdade, ele montou o primeiro banco mundial de sementes, abrigado em um antigo palácio tzarista na cidade de São Petersburgo (depois Leningrado).

No início do processo revolucionário que implantou o estado soviético, sob Lenin, a Ciência ainda era respeitada e muitos cientistas puderam relacionar-se com colegas de outros países. Vavilov foi enviado para uma missão aos EUA a fim de avaliar os métodos da agricultura norte-americana e comprar sementes que pudessem crescer na Rússia. Porém, vários fatores concorreram, desde 1918, para quedas progressivas nas colheitas, levando o povo russo a experimentar a fome.

Nessa viagem aos EUA, conheceu o laboratório de Thomas Hunt Morgan, que ganharia o prêmio Nobel de Fisiologia e Medicina de 1933 pelos trabalhos fundamentais na genética de Drosophila e que mostrou que os genes situavam-se em cromossomos, 
e Herrmann Muller, outro futuro nobelista (Prêmio Nobel de Fisiologia e Medicina de 1946) pelo trabalho em efeito de radiações nas mutações. Este último, sendo socialista, aceitou convite de Vavilov para uma estada prolongada na URSS, que ocorreu mais tarde, em 1930. Nessa viagem, Vavilov comprou 6.224 pacotes de sementes de 26 diferentes empresas de sementes norte-americanas (PRINGLE, 2008). A administração de Herbert Hoover enviou essas duas toneladas de sementes para o porto de Riga, junto com alimentos doados à Rússia como ajuda humanitária. Vavilov retornou à Rússia em fevereiro de 1922 e foi recompensado, tendo apenas 35 anos, com sua nomeação para membro correspondente da Academia de Ciências da URSS. Em pouco mais de um ano, Vavilov implantou 115 estações experimentais em diferentes latitudes do território soviético.

\section{TROFIM DENISOVICH LYSENKO}

A retórica de Lenin valorizava a "sabedoria popular". Certa vez, em correspondência enviada a Maximo Gorki, declarou certo desprezo aos intelectuais que, com sua empáfia, não resolviam nada versus o homem simples do povo, que ajudava na construção do socialismo. No entanto, deu muito apoio à Ciência e aos cientistas. Mas Lenin morreu em 1924, e Stalin o substituiu. A cultura do camponês sábio que estava incubando no regime revolucionário veio à tona.

Em 7 de agosto de 1927, o Pravda, órgão diário oficial do regime, publicou um artigo sobre um feito alcançado por Lysenko. Tratava-se de um plantio de ervilhas feito por ele, que havia sobrevivido ao inverno. O jornal referia-se a ele como um jovem cientista de pés descalços, um investigador prático de origem camponesa que não havia frequentado a universidade e que não se deixava atolar em um laboratório estudando "pernas peludas de moscas", mas indo "à raiz das coisas" (PRINGLE, 2008, p. 131). Era um claro ataque aos geneticistas e a Vavilov. O Pravda publicou matéria afirmando que esse feito da agricultura soviética por um camponês, técnico prático trabalhando no campo e sem complicações teóricas, atendia às necessidades da URSS no presente e não em um prazo de 10 anos (que era o tempo estimado por Vavilov para obter resultados de seus cruzamentos genéticos).

Lysenko era um camponês que conseguiu estudar - fato raro na época - em uma escola técnica de bom nível e era considerado um bom horticultor. No entanto, era descrito como oportunista. Lysenko aproveitou-se de uma técnica já conhecida, denominada vernalização. Esse é um processo pelo qual sementes hidratadas ou plântulas expostas a temperaturas baixas não congelantes são induzidas a florescer (TAIZ, 2002). No entanto, algumas variedades não respondem bem aos métodos de vernalização. $\mathrm{Na}$ verdade, a explicação de seu sucesso, naquele caso, foi a de que ele usou sementes da Ucrânia no Azerbaijão, e essas sementes eram de amadurecimento precoce. Com isso, frutificaram antes que o inverno congelante tivesse destruído tudo, como destruiu $90 \%$ do trigo plantado na Ucrânia no inverno de 1927-1928.

Estimulado pelos políticos e pelo jornal oficial, Lysenko passou a propagar que as características de resistência a frio adquiridas pelas sementes. Quando, por exemplo, eram guardadas no frio, seriam herdadas, reinventando o lamarckismo. Evidentemente, as críticas dos geneticistas a Lysenko foram unânimes, aumentando a tensão entre os 
defensores da Genética e o discurso oficial.

Stalin havia imposto a coletivização forçada da atividade agrícola, quando toda a produção passou para o Estado soviético, desestimulando os agricultores. Isso coincidiu com vários invernos rigorosos seguidos, que destruíram até $90 \%$ da produção de trigo e centeio, levando a fome ao território soviético. Stalin precisava de resultados rápidos e escolheu o discurso de Lysenko como a Biologia oficial. A Genética passou a ser chamada de Ciência burguesa ou capitalista, e muitos geneticistas foram acusados de serem suspeitos de espionagem em favor de países do ocidente. Detratores como Alexander Kol denunciaram que o plano de Vavilov de construir a maior coleção de sementes do mundo era "produto de botânica reacionária", exemplificada pela separação entre "a teoria e a prática" (ver Medvedev, Z. A., Rise and Fall of Trofim D. Lysenko, p. 18 e Joravsky, D., The Lysenko Affair, p. 77, citados por Pringle (2008), capítulo 15)

As consequências foram trágicas. Assim, em 1935, Stalin elogiou Lysenko explícita e publicamente, e este recompensou o mimo com um ataque aos geneticistas da URSS. Em 1936, Vavilov partiu para uma discussão pública com Lysenko e teve como recompensa o cancelamento, pelo governo, do 70 Congresso Internacional de Genética em Moscou. Em 1939, o 70 Congresso ocorreu em Edimburgo, Escócia, que elegeu Vavilov, em sua ausência, Presidente Honorário. Durante uma expedição científica à Ucrânia, Vavilov foi preso em 6 de agosto de 1940.

Durante quase dois anos (1940 - 1941), Vavilov foi interrogado pela NKVD, uma espécie de Ministério do Interior que controlava a polícia política do regime. O mesmo ocorreu com outros cientistas, particularmente com um discípulo e amigo de Vavilov, Georgy Karpechenko. É interessante que esse cientista foi contemporâneo de Theodosius Dobzhansky, tão importante para a genética brasileira. Quem quiser saber sobre os vínculos entre Dobzhansky e o Brasil pode consultar Monte Sião (2007). Vavilov trocou numerosas cartas com ambos, que estavam estagiando com Morgan na Columbia University e depois em Pasadena. Vavilov insistia que ambos deveriam voltar para ajudá-lo na imensa tarefa de obter variedades de sementes que fossem mais produtivas, já que a URSS lutava contra a fome. Karpechenko acabou voltando e foi empregado no Instituto de Botânica Aplicada dirigida por Vavilov. Dobzhansky, ao contrário, sempre se negou a voltar, discutindo acerbamente com Vavilov e argumentando que na URSS não havia liberdade para o desenvolvimento da Ciência. Salvou-se por ser consciente. Karpechenko foi aprisionado pela NKVD acusado falsamente de atividades antissoviéticas, sentenciado à morte e executado em 28 de julho de 1941. Ele era um dos que "contavam pelos em pernas de moscas" e foi acusado de praticar uma ciência despolitizada.

Em julho de 1941, Vavilov também foi condenado à morte por fuzilamento, acusado de sabotagem da agricultura Soviética e espionagem para o Reino Unido. Posteriormente, a sentença foi comutada para prisão por 20 anos de trabalhos forçados. Os países ocidentais tentavam prestigiá-lo como podiam, e, em 1942, a Royal Society o elegeu como membro estrangeiro. Não obstante, aos 26 de janeiro de 1943, com 56 anos, Vavilov morreu de desnutrição no Hospital-Prisão de Saratov. Para terminar sua obra nefasta, Stalin decretou, em 1948, que o lysenkismo seria a orientação oficial da Biologia Soviética e todos deveriam segui-la. Como consequência lógica, a biografia de Vavilov foi eliminada, em 1951, da segunda edição da Grande Enciclopédia Soviética. 
Assim, exemplifica-se a que ponto pode chegar a intromissão da política na Ciência. O Estado Soviético, por interesses ideológicos, revogou a Genética e mergulhou a União Soviética na escuridão, já que a Biologia e a Agricultura sofreram um baque do qual só se recuperaram pelo menos uma geração depois.

\section{A AGROECOLOGIA}

Em nossa opinião, qualquer disciplina nova que surja e que tenha veleidades de pertencer ao ramo da Ciência não deve ser reprimida, já que o método científico é inclemente em relação a afirmações não comprovadas. Sendo a Ciência uma atividade universal, que possui um mecanismo de autocorreção, outros cientistas irão, mais cedo ou mais tarde, verificar a veracidade das afirmações. No entanto, é preocupante quando a atividade agrícola que vem sendo aperfeiçoada desde a Revolução Verde, encetada por Norman Borlaug, ganhador do Prêmio Nobel da Paz de 1970, e que reforçou dramaticamente a segurança alimentar do Paquistão e da Índia e transformou o México em exportador de trigo, é descrita com pinceladas superficiais e sem nenhuma perspectiva histórica:

A primeira década do Século XXI revela um projeto de remontagem da modernização conservadora da agricultura, iniciada pelos militares, interrompida nos anos noventa e retomada como projeto de expansão primária para o setor externo nos últimos doze anos, sob a denominação de agronegócio, que se configura como nosso inimigo comum (ENU, 2012).

Portanto, segundo esse texto, a agroecologia é inimiga do agronegócio, o que causa estranheza se, de fato, a agroecologia fosse uma Ciência, já que não há exemplos de uma disciplina científica que tenha sido criada contra inimigos por ela identificados. $\mathrm{Na}$ verdade, são os inimigos da Ciência que tentam manietá-la, como aconteceu com Galileu e com Vavilov. Nenhuma das duas atividades, agroecologia e agronegócio, são Ciência. No entanto, o agronegócio já demonstrou que usa todo o progresso científico disponível para aumentar a eficiência, a produtividade e a renda. É até compreensível que haja movimentos alternativos que se insurjam contra o patenteamento de sementes e procurem maior justiça social, maior igualdade entre homens e mulheres, melhor distribuição de renda. No entanto, a fim de subsistir, esses movimentos devem levar resultados palpáveis ao agricultor.

Quando o autor deste texto desempenhava a função de Presidente da Comissão Técnica Nacional de Biossegurança (CTNBio, 2006 - 2010), foi possível compreender que grupos minoritários contrários à introdução das modernas tecnologias não tinham em mira, na verdade, o método ou a tecnologia, mas o fato de as propostas em análise, em sua grande maioria, terem origem em empresas capitalistas multinacionais. A CTNBio tem por finalidade a avaliação de riscos e não decidir seguindo uma interpretação "holística" pela mistura de considerações de ordem sócio-econômicas e geopolíticas. A Ciência medra em regimes democráticos porque pergunta livremente e tenta responder livremente. No processo, descobre ou inventa. Ela não é feita dirigida a grupos sociais específicos. 
Espera-se que o fato do conhecimento científico ser utilizado pelo agronegócio não rotule a Genética moderna de "ciência burguesa" ou "ciência capitalista", porque esse discurso não seria original, como demonstram as incríveis semelhanças de terminologia entre o período totalitário da URSS na primeira metade do século XX e o discurso de alguns que professam a agroecologia.

De fato, a agroecologia não foi definida ainda. Certamente não é Ciência nem disciplina científica. Resta concluir, como Navarro (3013), que a agroecologia é uma tentativa de propor uma abordagem alternativa ao padrão técnico-científico dominante da agricultura moderna com forte componente político e cujas metas são outras, menos o desenvolvimento de uma ciência nova.

A agroecologia é apenas um movimento político do qual fazem parte muitos membros do CONSEA, cuja sede está no Palácio do Planalto ${ }^{3}$.

\section{REFERÊNCIAS}

CONSEA. Conselho Nacional de Segurança Alimentar e Nutricional. Boletim do Consea de 25 de abril de 2012. Brasília: CONSEA, 2012.

ENU. Declaração do Encontro Nacional Unitário dos trabalhadores(as) e povos do campo, das águas e das florestas. Brasília: Anais do ENU, 2012.

MONTE SIÃO, J. F. As contribuições de Theodosius Dobzhansky ao desenvolvimento da genética no Brasil (1943 - 1960): um estudo bibliométrico. Revista Filosofia e História da Biologia, São Paulo: Associação Brasileira de Filosofia e História da Biologia (ABFHiB), 2007.

NAVARRO, Z. Agroecologia: as coisas em seu lugar (a Agronomia brasileira visita a terra dos duendes) Colóquio - Revista do Desenvolvimento Regional - Faccat, Taquara, v. 10, n. 1, jan./jun. 2013.

PRINGLE, P. The murder of Nikolai Vavilov. New York: Simon and Schuster, 2008.

TAIZ, L. The control of flowering. In: Taiz, L.; Zeiger, E. (Eds.). Plant Physiology. Sunderland: Sinauer Associates, 2002.

\footnotetext{
${ }^{3}$ Consultar o site do Conselho Nacional de Segurança Alimentar e Nutricional (disponível em $<$ www.presidencia.gov.br/consea>). 